\title{
Prosedur Pendistribusian Zakat pada BAZNAS Kabupaten Tanah Datar di Tengah Pandemi Covid-19
}

\section{Zakat Distribution Procedure at BAZNAS Tanah Datar District Amid the Covid-19 Pandemic}

\author{
Widi Nopiardo, Wulan Yulia Sandani \\ Fakultas Ekonomi dan Bisnis Islam, Institut Agama Islam Negeri Batusangkar \\ widinopiardo@iainbatusangkar.ac.id, wulanys2211@gmail.com
}

Manuscript received 31 Maret 2021, processed 10 April 2021, published 30 Juni 2021

\begin{abstract}
The procedure for distributing zakat at BAZNAS Tanab Datar Regency in the midst of the covid19 pandemic. The purpose of this discussion is to find out the procedure for distributing zakat at $B A Z N A S$ Tanah Datar Regency in the midst of the covid-19 pandemic and the obstacles faced by BAZNAS Tanah Datar Regency in the midst of the COVID-19 pandemic. The type of research that the author uses is a type of field research (field research), to obtain data from the problems studied. Data collection techniques that the authors use is through interviews and documentation. Data analysis techniques using data display techniques, data reduction, and drawing conclusions. From the research that the author conducted in the field, it can be concluded that the procedure for distributing rakat at BAZNAS Tanah Datar Regency in the midst of the Covid-19 Pandemic is not much different from before the Covid-19 pandemic, during the Covid-19 pandemic there were additional distribution techniques, such as: distributing PPE for amil who are on duty to the field, providing supplements for the amil body's defense and when distributing mustabik are reminded to obey health protocols Meanwbile, the obstacles that occurred during the covid-19 pandemic were not able to collect mustabik in large numbers so that the Tanah Datar Regency BAZNAS shortened existing procedures, for example, there was no provision for mustabik during the Covid-19 pandemic.
\end{abstract}

Keywords: Zakat, Distribution, Covid-19.

Abstrak: Prosedur pendistribusian zakat di BAZNAS Kabupaten Tanah Datar di tengah pandemi covid-19. Tujuan pembahasan ini untuk mengetahui prosedur pendistribusian zakat di BAZNAS Kabupaten Tanah Datar di tengah pandemi covid19 dan kendala yang dihadapi oleh BAZNAS Kabupaten Tanah Datar di tengah pandemi covid-19. Jenis penelitian yang penulis gunakan adalah jenis penelitian lapangan (field research), untuk mendapatkan data-data dari permasalahan yang diteliti. Teknik pengumpulan data yang penulis gunakan adalah melalui wawancara dan dokumentasi. Teknik analisis data dengan menggunakan teknik display data, reduksi data, serta penarikan simpulan. Dari penelitian yang penulis lakukan di lapangan dapat disimpulkan bahwa prosedur pendistribusian zakat di BAZNAS Kabupaten Tanah Datar di tengah Pandemi Covid-19 tidak jauh berbeda dengan sebelum masa pandemi Covid-19, pada masa pandemi Covid-19 terjadi terjadi penambahan teknik dalam penditribusian, seperti: membagikan APD untuk amil yang bertugas ke lapangan, memberikan suplemen untuk pertahanan tubuh amil serta ketika penyaluran mustahik diingatkan untuk mematuhi protokol kesehatan. Sedangkan kendala yang terjadi selama pandemi covid-19 tidak dapat mengumpulkan mustahik dalam jumlah banyak sehingga BAZNAS Kabupaten Tanah Datar mempersingkat prosedur yang ada, contohnya tidak adanya pembekalan yang diberikan kepada mustahik di saat pandemi Covid-19 ini.

Kata Kunci: Zakat, Pendistribusian, Covid-19 


\section{PENDAHULUAN}

Zakat merupakan salah satu dari Rukun Islam yang merupakan "mahdhab" dalam bidang materi. Karena termasuk dalam ibadah mahdhah maka dasar pensyariatannya dikukuhkan dalam al-Qur'an dan al-Sunnah dengan berbgai pendekatan seperti ajakan himbauan pahala bagi orang- orang yang melaksanakannya dan ancaman bagi orang yang meninggalkannya. (Abbas, 2017: 7) .

Zakat sebagai ibadah bersifat maliya ijtima'iyah, harus dikelola dengan cara yang profesional. Karena pengelolaan yang profesiaonal akan meningkatkan peluang membaiknya pelayanan bagi masyarakat dalam menunaikan zakat sesuai dengan ketentuan agama. Apa lagi zakat memiliki fungsi dan peranan mewujudkan kesejahteraan masyarakat dan ketidak adilan sosial sehingga dapat meningkatkan hasil guna dan daya guna zakat. Pengelolaan zakat di Indonesia dilakukan oleh Badan Amil Zakat dan Lembaga Amil Zakat dengan cara menerima atau mengambil harta atau barang zakat dari muzakki atas dasar pemberitahuan muzakki. (Zabir, Muzakkir, 2017: 4) .

Zakat merupakan instrumen yang urgen dalam sektor ekonomi Islam dan mendorong kesejahteraan umat Islam di dunia, dengan demikian organisasi pengelolah zakat (OPZ) perlu diatur dan dikelola secara efektif dan efisien. Melalui sistem pengumpulan, pendistribusian dan pendayahgunaan yang baik zakat dapat menjadi alternatif kestabilan krisis sekonomi dunia (Nopiardo, 2021: 2).

Pengelolaan zakat ini memerlukan penguatan dari sisi regulasinya, yakni UndangUndang, Peraturan Pemerintah, Peraturan Menteri, dan Peraturan Daerah. Penguatan sinergi antar sesama komponen dari pengelolaan zakat. (Asmawi, 2017: 2) .

Undang-undang Nomor 23 Tahun 2011 Tentang Pengelolaan Zakat. Disusul dengan terbitnya Peraturan Pemerintah
Republik Indonesia Nomor 14 Tahun 2014 tentang Pelaksanaan Undang-undang Nomor 23 Tahun 2011 tentang Pengelolaan Zakat. Undang-undang ini dibuat untuk mengoptimalkan pendistribusian zakat yang bertujuan untuk pemerataan ekonomi dan pembangunan umat. (Saifuddin, 2013: 2) .

Pendistribusian zakat adalah suatu aktifitas atau kegiatan untuk mengatur sesuai dengan fungsi manajemen dalam upaya menyalurkan dana zakat yang diterima dari pihak muzakki kepada mustahik sehingga tercapainya tujuan dari sebuah organisasi secara efektif. Pengelolaan dan distribusi zakat di Indonesia ada dua macam, yaitu distribusi secara konsumtif dan distribusi secara produktif. (Mukhlisin, 2009: 47) .

Dalam pengelolaan zakat ini ada lembaga yang mendistribusikan dana zakat, lembaga tersebut dinamakan Badan Amil Zakat Nasional. Di Kabupaten Tanah Datar telah di bentuk Badan Amil Zakat Nasional Kabupaten Tanah Datar oleh pemerintah Kabupaten Tanah Datar melalui SK Bupati dan berkedudukan di ibu kota kabupaten. Sejak berdiri tahun 1999, BAZNAS Kabupaten Tanah Datar telah melalui beberapa periode kepengurusan. Pada awalnya lembaga ini disebut BAZIS, kemudian berubah nama menjadi BAZ, sampai akhirnya disebut BAZNAS sejak tahun 2011. BAZNAS kabupaten/ kota melaksanakan tugas dan fungsi BAZNAS di kabupaten/ kota tersebut (UU RI Nomor 23 Tahun 2011 Tentang Pengelolaan Zakat). Dengan demikian, BAZNAS Tanah Datar juga berkewajiban melaksanakan tugas dan fungsi BAZNAS di kabupaten Tanah Datar. (Fahlefi, 2016: 102103)

Berikut ini gambaran pendistribusian zakat pada BAZNAS Kabupaten Tanah Datar dari Tahun 2016-2020. 
Tabel 1

Jumlah Pendistribusian Zakat pada Tahun

2016-2020

\begin{tabular}{|c|c|}
\hline Tahun & Jumlah (Rp) \\
\hline 2016 & 9.079 .113 .287 \\
\hline 2017 & 7.860 .007 .018 \\
\hline 2018 & 9.102 .401 .718 \\
\hline 2019 & 6.494 .658 .590 \\
\hline 2020 & 8.450 .081 .122 \\
\hline
\end{tabular}

Sumber: Olahan Penulis

Pada tebel di atas terlihat bahwa jumlah Pendistribusian zakat dari tahun 2016 sampai dengan bulan Juli tahun 2020 mengalami peningkatan dan penurunan.

Pada saat sekarang ini dunia sedang diserang oleh wabah virus yang dinamakan Covid-19. Covid-19 atau Coronavirus adalah virus RNA dengan ukuran partikel 120-160 $\mathrm{nm}$. Virus ini utamanya menginfeksi hewan, termasuk di antaranya adalah kelelawar dan unta. Sebelum terjadinya wabah Covid-19, ada 6 jenis coronavirus yang dapat menginfeksi manusia, yaitu alphacoronavirus 229E, alphacoronavirus NL63, betacoronavirus OC43, betacoronavirus HKU1, Severe Acute Respiratorn Illness Coronavirus (SARS-CoV), dan Middle East Respiratory Syndrome Coronavirus (MERS-CoV). (Jurnal Penyakit Dalam Indonesia, 2020, hal.2).

Wabah Covid-19 menyebabkan masyarakat dilarang untuk beraktifitas keluar rumah dan membatasi berinteraksi dengan orang banyak. Ketika akan keluar rumah masyarakat diharuskan untuk memenugi protokol kesehatan, seperti memakai masker dan menjaga jarak dengan orang lain. Hal ini menyebabkan terhambatnya berbagai aktifitas masyarakat yang biasa dilakukan sehari-hari. Masyarakat harus mematuhi protokol kesehatan agar terhindar dari wabah Covid-19. Wabah ini mengakibatkan aktifitas perkantoran sempat dihentikan, sekolah dan kampus diliburkan sampai saat ini, objek wisata sempat ditutup, aktifitas keluar kota dilarang dan masih banyak yang harus di patuhi oleh masyarakat. (Riko A, Wawancara, 30 Agustus 2020) .

Sesuai dengan Surat Edaran Gubernur Sumatera Barat Nomor 360/056/COVID-19SBR/IV-2020 tentang Petunjuk Teknis Pelaksanaan Pembatasan Sosial Berskala Besar aktivitas bekerja di tempat kerja/kantor pada Kabupaten/Kota di Sumatera Barat. Pada Surat Edaran ini dijelaskan bahwa selama pemberlakukan PSBB, dilakukan penghentian sementara aktivitas bekerja di tempat kerja/kantor. Dengan adanya pembatasan aktivitas kerja mengkehendaki BAZNAS Kabupaten Tanah Datar tentu menyesuaikan kebijakan tentang prosedur pendistribusian zakat dengan peraturan yang ada. (Riko A, Wawancara, 30 Agustus 2020) .

Dari situasi yang terjadi ini berimbas pada pendistribusian di BAZNAS Kabupaten Tanah Datar yang mana pada proses administrasi akan menjadi singkat, dan realisasi pendistribusian zakat cenderung menurun setiap periode semester 2020, serta penundaan atau keterlambatannya program yang akan dilaksanakan oleh BAZNAS Kabupaten Tanah Datar.(Riko A, Wawancara, 30 Agustus 2020) .

\section{METODE PENELITIAN}

Penelitian yang penulis lakukan adalah field research atau penelitian lapangan yaitu yang dilakukan pada Badan Amil Zakat Nasional (BAZNAS) Kabupaten Tanah Datar. Metode penelitian yang digunakan adalah metode kualitatif yaitu melihat bagaimana prosedur pendistribusian zakat pada BAZNAS Kabupaten Tanah Datar di tengah pandemi Covid-19 dan berapa banyak zakat yang di distribusikan pada BAZNAS Kabupaten Tanah Datar selama masa pandemi Covid-19. 


\section{PEMBAHASAN}

Prosedur Pendistribusian Zakat Pada BAZNAS Kabupaten Tanah Datar di tengah Pandemi Covid-19

Zakat sangat penting dan merupakan suatu kewajiban bagi umat Islam, jadi melaksanakannya di negara diatur dalam UU No 23 tahun 2011 tentang Pengelolaan Zakat. Untuk itu BAZNAS Kabupaten Tanah Datar hadir di tengah-tengah masyarakat untuk membantu seluruh masyarakat yang membutuhkan di saat kondisi pandemi maupun tidak saat pandemi.

Pendemi Covid-19 membuat berbagai macam persoalan dan memberikan keterbatasan dalam melakukan berbagai aktifitas pekerjaan, banyak hal yang terhambat bahkan tidak dapat terjalankan, dan harus mematuhi protokol kesehatan yang telah ditetapkan pemerintah. Tetapi BAZNAS Kabupaten Tanah Datar tetap menjalankan program-programnya untuk memberikan pelayanan kepada masyarakat terkait keluhan dan permasalahan yang disampaikan kepada BAZNAS Kabupaten Tanah Datar.

Program-program pendistribusian yang ada di BAZNAS Kabupaten Tanah Datar:

1. Program Pendidikan

Program pendidikan adalah pemberian bantuan untuk mendukung proses pendidikan bagi siswa / mahasiswa dari keluarga yang tidak mampu di Kabupaten Tanah Datar. (Dokumen BAZNAS Kabupaten Tanah Datar, 2020) .

2. Program Ekonomi

Program ekonomi merupakan bantuan modal usaha yang diberikan kepada keluarga miskin untuk melaksanakan usaha produktif seperti bertani, beternak, berdagang dan usaha lainnya. (Dokumen BAZNAS Kabupaten Tanah Datar, 2020) .
3. Program Kemanusiaan

Program kemanusiaan adalah program bantuan yang diberikan kepada mustahik zakat dalam bentuk, bantuan konsumtif lebaran, bantuan konsumtif permanen, bantuan korban bencana, dan bantuan bedah rumah. (Dokumen BAZNAS Kabupaten Tanah Datar, 2020)

Adapun rincian dari program kemanusian ini tergambar pada keterangan berikut:

a. Bantuan konsumtif lebaran adalah bantuan insidentil yang diberikan kepada mustahik (fakir miskin) untuk menghadapi Hari Raya 'Idul Fitri. (Dokumen BAZNAS Kabupaten Tanah Datar, 2020) .

b. Bantuan konsumtif permanen adalah bantuan rutin yang diberikan kepada mustahik (fakir miskin) yang tidak bisa berusaha disebabkan faktor usia atau cacat permanen dan tidak memiliki keluarga atau sanak famili yang menanggung kebutuhan hidupnya sehari-hari. (Dokumen BAZNAS Kabupaten Tanah Datar, 2020) .

c. Bantuan untuk korban bencana yaitu bantuan yang diberikan kepada mustahik di Kabupaten Tanah Datar yang mendapat musibah atau bencana seperti kebakaran, longsor, atau bencana lainnya. (Dokumen BAZNAS Kabupaten Tanah Datar, 2020) .

d. Bantuan untuk bedah rumah yaitu bantuan dalam bentuk dana stimulan untuk perbaikan atau pembangunan rumah bagi mustahik yang tidak memiliki rumah layak huni di Kabupaten Tanah Datar. (Dokumen BAZNAS Kabupaten Tanah Datar, 2020) .

4. Program Kesehatan 


\begin{abstract}
Program kesehatan adalah program bantuan biaya berobat yang diberikan kepada keluarga mustahik zakat. (Dokumen BAZNAS Kabupaten Tanah Datar, 2020) .
\end{abstract}

5. Program Dakwah dan Advokasi

Program dakwah dan advokasi adalah program peningkatan pengetahuan, pemahaman dan pengamalan agama Islam masyarakat Kabupaten Tanah Datar. (Dokumen BAZNAS Kabupaten Tanah Datar, 2020).
6. Zakat Community Development Program Zakat Community Development (ZCD) adalah proses jangka panjang dengan mengintegrasikan program-program untuk mengatasi masalah kesehatan, pendidikan, ekonomi dan masalah sosial, dengan menggunakan dana Zakat Infak Shodaqoh, diharapkan ada perubahan yang sangat signifikan dengan adanya program ZCD, dengan partisipasi komunitas/masyarakat, dengan segala fasilitas dan teknologi yang diinovasikan pada suatu program. (Dokumen BAZNAS Kabupaten Tanah Datar, 2020).

Tabel 2

Prosedur Pendistribusian Zakat

\begin{tabular}{|c|c|c|}
\hline No. & $\begin{array}{c}\text { Nama } \\
\text { Program }\end{array}$ & Prosedur Pendistribusian Zakat \\
\hline 1. & $\begin{array}{c}\text { Program } \\
\text { Pendidikan }\end{array}$ & $\begin{array}{l}\text { Adapun prosedur pendistribusian zakat beasiswa tingkat SD dan } \\
\text { SMP secara umum sebagai berikut: } \\
\text { 1. Membagi kuota dengan merujuk kepada persentase zakat yang } \\
\text { masuk dari kecamatan. } \\
\text { 2. Menurunkan surat kepada UPZ Kecamatan yang telah disetujui oleh } \\
\text { pimpinan. } \\
\text { 3. Mengirim surat ke Kecamatan untuk meminta data pengusul calon } \\
\text { mustahik penerima beasiswa, dengan waktu paling lama } 15 \text { hari atau } \\
2 \text { minggu. } \\
\text { 4. Menerima surat balasan dan direkap kembali di bagian } \\
\text { pendistribusian, dan menyampaikannya kepada kepala pelaksana } \\
\text { untuk ditindak lanjuti kepada pimpinan. } \\
\text { 5. Membuat Permohonan Pencairan Dana (PPD) di bagian keuangan } \\
\text { sesuai dengan kuota yang ada, lalu dananya dicairkan. } \\
\text { 6. Membagikan Alat Pelindung Diri (APD) dan suplemen untuk } \\
\text { pertahanan tubuh amil saat berada di lapangan. } \\
\text { 7. Mendistribusikan zakat kepada mustahik dengan tetap mematuhi } \\
\text { protokol kesehatan pada tempat yang telah ditentukan. } \\
\text { 8. Mempersingkat prosedur pada program beasiswa pendidikan yang } \\
\text { mana biasanya pimpinan menyampaikan arahan kepada mustahik } \\
\text { secara bersama, di saat pandemi mustahik dibagi beberapa shift, } \\
\text { dengan cara bergantian sekaligus diberikan arahan oleh pimpinan } \\
\text { kepada mustahik secara individu } \\
\text { Adapun prosedur pendistribusian zakat beasiswa untuk tingkat } \\
\text { perguruan tinggi secara umum sebagai berikut: } \\
\text { 1. Calaon mustahik membuat proposal yang ditujukan kepada }\end{array}$ \\
\hline
\end{tabular}

Online Access: http://ecampus.iain6atusangkar.ac.id/ojs/index.php/zawa| 51 


\begin{tabular}{|c|c|c|}
\hline & & $\begin{array}{l}\text { pimpinan BAZNAS Kabupaten Tanah Datar. } \\
\text { 2. Memverifikasi proposal calon mustahik. } \\
\text { 3. Mensurvey calon mustahik. } \\
\text { 4. Menetapkan mustahik zakat beasiswa. } \\
\text { 5. Membuat PPD di bagian keuangan sesuai dengan ketentuan. } \\
\text { 6. Membagikan Alat Pelindung Diri (APD) dan suplemen untuk } \\
\text { pertahanan tubuh amil saat berada di lapangan. } \\
\text { 7. Mendistribusikan zakat kepada mustahik dengan tetap mematuhi } \\
\text { protokol kesehatan pada tempat yang telah ditentukan. } \\
\text { 8. Mempersingkat prosedur pada program beasiswa pendidikan yang } \\
\text { mana biasanya ada pembinaan, namun di saat pandemi hal tersebut } \\
\text { tidak dilakukan. Mustahik dibagi beberapa shift, dengan cara } \\
\text { bergantian sekaligus diberikan arahan secara ringkas oleh pimpinan. }\end{array}$ \\
\hline 2. & $\begin{array}{l}\text { Program } \\
\text { Ekonomi }\end{array}$ & $\begin{array}{l}\text { 1. Membagi kuota dengan merujuk kepada persentasi zakat yang } \\
\text { masuk dari kecamatan. } \\
\text { 2. Menurunkan surat kepada UPZ Kecamatan yang telah disetujui oleh } \\
\text { pimpinan. } \\
\text { 3. Menurunkan surat kepada OPD yang ada di kantor bupati agar } \\
\text { dapat mengusulkan calon mustahik untuk bantuan ekonomi } \\
\text { profuktif. } \\
\text { 4. Menginput data dibagian pendistribusian. } \\
\text { 5. Mengajukan data kepada kepala pelaksana untuk dilaporkan kepada } \\
\text { pimpinan. } \\
\text { 6. Pimpinan menyetujui dan dibuatkan PPD untuk dilakukan proses } \\
\text { pencairan dana. } \\
\text { 7. Membagikan APD dan suplemen untuk pertahanan tubuh amil saat } \\
\text { berada di lapangan. } \\
\text { 8. Mendistrisbusikan zakat kepada mustahik dengan tetap mematuhi } \\
\text { protokol kesehatan. } \\
\text { 9. Mempersingkat perosedur pada program ekonomi yang mana } \\
\text { biasanya pimpinan melakukan pembinaan sesuai bidang usahanya } \\
\text { dalam kurun waktu tertentu, namun di saat pandemi mustahik dibagi } \\
\text { beberapa shift, dengan cara bergantian untuk mendapatkan arahan } \\
\text { tentang pendistribusian zakat produktif. }\end{array}$ \\
\hline 3. & $\begin{array}{c}\text { Program } \\
\text { kemanusiaan }\end{array}$ & $\begin{array}{l}\text { 1. Konsumtif Lebaran } \\
\text { a. Membagi kuota dengan merujuk kepada persentasi zakat } \\
\text { yang masuk dari kecamatan. } \\
\text { b. Menurunkan surat kepada UPZ Kecamatan yang telah } \\
\text { disetujui oleh pimpinan. } \\
\text { c. Menurunkan surat kepada OPD yang ada di kantor bupati, } \\
\text { agar dapat mengusulkan calon mustahik untuk bantuan } \\
\text { konsumtif lebaran ini. } \\
\text { d. Menginput data di bagian pendistribusian. }\end{array}$ \\
\hline
\end{tabular}




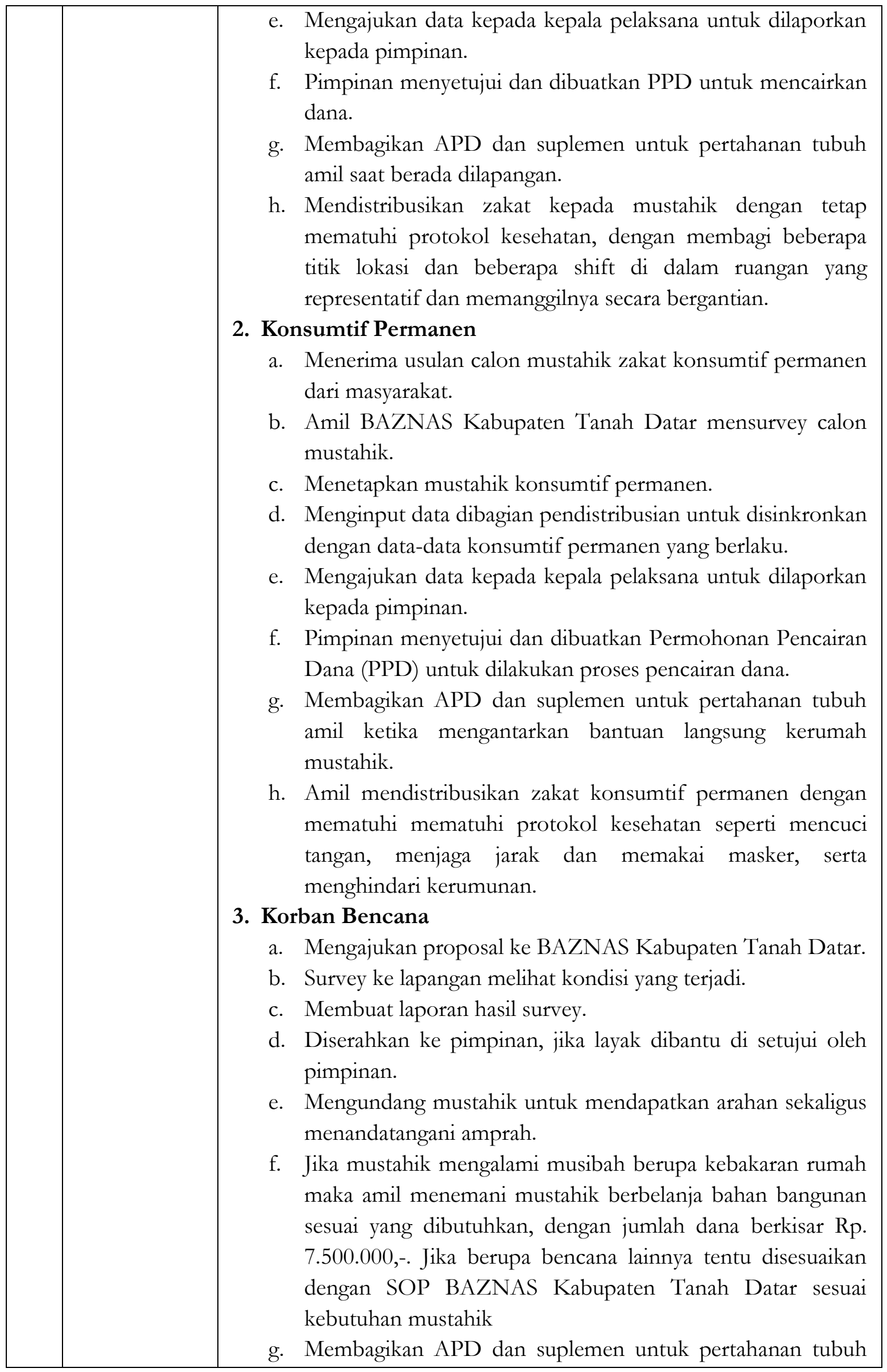




\begin{tabular}{|c|c|c|}
\hline & & $\begin{array}{l}\text { amil ketika mengantarkan mustahik untuk berbelanja ke } \\
\text { toko bangunan atau menyalurkan bantuan berupa sembako } \\
\text { kepada mustahik. } \\
\text { h. Amil dan mustahik diharuskan mematuhi protokol } \\
\text { kesehatan dengan tetap mencuci tangan, memakai masker, } \\
\text { menjaga jarak, dan menghindari kerumunan. } \\
\text { 4. Bedah Rumah } \\
\text { a. Mustahik membuat RAB (rencana anggaran biaya) dengan } \\
\text { dana Rp. 25.000.000,- sesuai dengan kebutuhan yang } \\
\text { diperlukan. } \\
\text { b. Mengajukan data kepada kepala pelaksana untuk dilaporkan } \\
\text { kepada pimpinan. } \\
\text { c. Pimpinan menyetujui dan dibuatkan Permohonan Pencairan } \\
\text { Dana (PPD) untuk dilakukan proses pencairan dana. } \\
\text { d. Amil pelaksana yang ditugaskan di kecamatan yang akan } \\
\text { mendampingi mustahik untuk berbelanja ke toko bangunan. } \\
\text { e. Membagikan APD dan suplemen untuk pertahanan tubuh } \\
\text { amil ketika mengantarkan mustahik untuk berbelanja ke } \\
\text { toko bangunan. } \\
\text { f. Amil dan mustahik diharuskan mematuhi protokol } \\
\text { kesehatan dengan tetap menjaga jarak dan menghindari } \\
\text { kerumunan. }\end{array}$ \\
\hline 4. & $\begin{array}{l}\text { Program } \\
\text { Kesehatan }\end{array}$ & $\begin{array}{l}\text { 1. Mustahik mengajukan proposal bantuan berobat ke BAZNAS } \\
\text { Kabupaten Tanah Datar. } \\
\text { 2. Amil melakukan survey kepada calon mustahik. } \\
\text { 3. Membuat laporan survey dan diberikan kepada bagian } \\
\text { pendistribusian. } \\
\text { 4. Menghubungi mustahik untuk datang ke kantor BAZNAS guna } \\
\text { mengambil bantuannya. Pada kondisi tertentu amil bisa saja } \\
\text { mengantarkan bantuan tersebut kepada mustahik langsung. } \\
\text { 5. Membagikan APD dan suplemen untuk pertahanan tubuh amil } \\
\text { ketika menunggu mustahik di kantor BAZNAS Kabupaten Tanah } \\
\text { Datar atau di lapangan. } \\
\text { 6. Amil dan mustahik diharuskan mematuhi protokol kesehatan } \\
\text { dengan tetap menjaga jarak dan menghindari kerumunan. }\end{array}$ \\
\hline 5. & $\begin{array}{l}\text { Program } \\
\text { Dakwah dan } \\
\text { Advokasi }\end{array}$ & $\begin{array}{l}\text { 1. Membuka Open Recuitment (OR). } \\
\text { 2. Bagian pendistribusian menyeleksi calon dai BAZNAS Kabupaten } \\
\text { Tanah Datar. } \\
\text { 3. Memberikan pelatihan kepada dai yang lulus seleksi. } \\
\text { 4. Menempatkan dai di daerah yang "minus dakwah". } \\
\text { 5. Memberikan laporan kepada bagian pendistribusian. } \\
\text { 6. Memberikan ujrah kepada dai sesuai dengan SOP. } \\
\text { 7. Membagikan APD dan suplemen untuk pertahanan tubuh dai ketika }\end{array}$ \\
\hline
\end{tabular}




\begin{tabular}{|l|l|l|}
\hline & & $\begin{array}{l}\text { berada di daerah penempatannya . } \\
\text { 8. Dai diharuskan mematuhi protokol kesehatan dengan tetap menjaga } \\
\text { jarak dan menghindari kerumunan. }\end{array}$ \\
\hline 6 & Program ZCD & $\begin{array}{l}\text { Tidak ada program khusus di tahun 2020, hanya melaksanakan proses } \\
\text { lanjutan dari ZCD tahun sebelumnya berupa pemantauan-pemantauan } \\
\text { ke lapangan dengan mematuhi protokol kesehatan. }\end{array}$ \\
\hline
\end{tabular}

Sumber: Olahan Penulis

Berdasarkan paparan tabel di atas dapat dilihat bahwasanya program pendistribusian yang ada di BAZNAS Kabupaten Tanah Datar selama pandemi Covid-19 terlaksana sebanyak lima program dan satu program yang tidak terlaksana. Persentasi dari program pendistribusian yang terlaksana selama pandemi Covid-19 sebanyak 90\%. Sedangkan kendala yang terjadi selama pandemi covid-19 tidak dapat mengumpulkan mustahik dalam jumlah banyak, sehingga BAZNAS Kabupaten Tanah Datar mempersingkat prosedur yang ada, contohnya tidak adanya pembekalan yang diberikan kepada mustahik di saat pandemi Covid-19 ini.

\section{KESIMPULAN}

Berdasarkan uraian-uraian dalam babbab sebelumnya tentang Prosedur dan kendala Pendistribusian Zakat pada BAZNAS Kabupaten Tanah Datar pada masa pandemi Covid-19, maka hasil penelitian ini dapat disimpulkan bahwa:

Secara keseluruhan prosedur pendistribusian zakat di BAZNAS Kabupaten Tanah Datar di tengah Pandemi Covid-19 tidak jauh berbeda dengan sebelum masa pandemi Covid-19, pada masa pandemi Covid19 terjadi terjadi penambahan teknik dalam penditribusian, seperti: membagikan APD untuk amil yang bertugas ke lapangan, memberikan suplemen untuk pertahanan tubuh amil serta ketika penyaluran mustahik diingatkan untuk mematuhi protokol kesehatan. Sedangkan kendala yang terjadi selama pandemi covid-19 tidak dapat

mengumpulkan mustahik dalam jumlah banyak, sehingga BAZNAS Kabupaten Tanah Datar mempersingkat prosedur yang ada, contohnya tidak adanya pembekalan yang diberikan kepada mustahik di saat pandemi Covid-19 ini.

\section{DAFTAR KEPUSTAKAAN}

Jurnal Penyakit Dalam Indonesia. 2020. Coronavirus disease 2019: Tinjauan Literatur Terkini, Vol. 7, No. 1, Maret.

Abbas, A. S. 2017. Zakat ketentuan dan pengelolaannya. Bogor, Jawa Barat: CV. Anugrahberkah Sentosa.

Asmawi. 2017. Kontekstualisasi Hukum Zakat Di Indonesia .Istinbáth Jurnal Hukum Islam Vol. 16, No. 1, Juni .

Fahlefi, R. 2016. Perkembangan Pengumpulan Zakat Pada Baznas Kabupaten Tanah Datar Periode 2010 S.D. 2014 .Xuqdo,Opldk6\Dulqah, Volume 15, Nomor 1, Januari-Juni

Mukhlisin. 2009. Pendistribusian Dana Zakat Untuk Pemberdayaan Ekonomi Masyarakat pada BAZDA Kab. Karawang.

Nopiardo, Widi. 2021. Strategi Pendistribusian Zakat Produktif Perdagangan pada $B A Z N$ AS Kota Padang Panjang. JISFIM: Journal of Islamic Social Finance Management Volume 2 Nomor 1 Ed. Jan-Juni

Riko A. 2020. Wawancara, 30, Agustus.

Saifuddin. 2013. Optimalisasi Distribusi Dana Zakat: Upaya Distribusi Kekayaan (Studi terhadap UU No. 23 Tahun 2011 tentang

Onfine Access: http://ecampus.iain6atusangkar.ac.id/ojs/index.php/zawa| 55 
Pengelolaan Zakat) . Az Zarqa', Vol. 5, No. 2, Desember .

Zabir, M. 2017. Manajemen Pendistribusian

Zakat Melalui Program Unggulan Beasiswa
Oleh Baitul Mal Aceh. Al-Idarah, Vol. 1, No. 1, Januari - Juni 